\title{
DESCRIPTIONS OF ONE NEW GENUS AND EIGHT NEW SPECIES OF ICHNEUMON-FLIES.
}

\author{
By H. L. VIERECK, \\ Bureau of Entomology, U. S. Department of Agriculture.
}

In the present paper a number of names are proposed that are about to be used in a Bulletin by Dr. L. O. Howard and Mr. F. W. Fiske on the importation into the United States of the parasites of the gipsy and brown-tail moths. This Bulletin is to be published shortly by the U. S. Department of Agriculture, Bureau of Entomology.

Family BRACONIDÆ.

APANTELES (APANTELES) LACTEICOLOR, new species.

Female.-Length, $2.5 \mathrm{~mm}$.; in structure and sculpture this agrees best with $A$. contaminatus Haliday as defined by T. A. Marshall; it differs materially, however, in having the propodeum provided with a clearly defined areola flanked by two distinct areas on each side, the boundaries being distinct septa and the interstices smooth and polished; the petiolarea is virtually wanting, the basal area not clearly circumscribed but rugose within; stigma not transparent but paler than the boundary.

Male.-Sufficiently similar to the female to be easily associated therewith; stigma agreeing well with A. lacteus as described by T. A. Marshall.

Type--Male and female, Cat. No. 13072, U.S.N.M.

Type-locality.-Europe, Gipsy Moth Laboratory Cage, No. 515, June 24, 1907.

Paratypes.-Gipsy Moth Laboratory Cage, No. 515 and Nos. 1446, 682, 501, 238, 205, 1042, 1248, and 1295, U. S. Department of Agriculture, Bureau of Entomology.

In some of the female paratypes the stigma is transparent, but not clearly as in the male nor whitish as in the male. Specimens Nos. 1042 and 1248 are labeled "Bred from E. chrysorrhoea."

Out of 78 females studied, four were noted to have a reduction of the postmedian expansion of the first tergite, making the sides nearly parallel and the segment nearly twice as long as wide at apex or at base; this departure from the apparent normal is even more marked in a small minority of the 54 males studied, the parallel sides of the first tergite in these becoming at least twice as long as wide at base or at apex. 


\section{PARAPANTELES Ashmead.}

In structure and sculpture Apanteles lacteicolor Viereck is very similar to the type of Parapanteles Ashmead. Typical Apanteles and typical Parapanteles can be separated only on characters of at most specific value, hence it becomes necessary to include Parapanteles as a synonym of Apanteles Foerster.

\section{CHELONUS BIPUSTULATUS, new species.}

Female.-Length $5 \mathrm{~mm}$; head black, dullish, sculptured, proportionally as in the genotype; clypeus not compressed apically, the apical edge subemarginate; malar space separated from the face by a bandlike area of fine sculpture; cheeks plicately striate; antennæ black, more than 24-jointed, of the same form as in the genotype; first joint of flagel about two-thirds the length of the scape; mandibles partly testaceous; palpi fuscous; thorax essentially as in the genotype; wings transparent, with a brownish tinge throughout; most of veins and the stigma dark brown; coxæ and trochanters black; basal half of femora entirely or mostly black or blackish, the apical half of the same more or less testaceous; tibiæ yellowish, the hind pair with a subbasal and apical blackish band; tarsi fuscous with the basal joint more or less pale; carapace hardly twice as long as wide, simple at apex, uniformly sculptured and black except for two subbasal yellow maculæ.

Type-locality.-Chile.

Type.-Cat. No. 13796, U.S.N.M.

The type was presumably collected by E. C. Reed.

CYANOPTERIDEA, nevv genus.

This is the same as Cyanopterus Szepligeti not of Haliday.

Type of the genus. - (Iphiaulax) Cyanopterus clypeolus Szepligeti.

Mr. Roman has pointed out that the genotype of Cyanopterus Haliday and Bracon orbitalis Cresson are congeneric. With this conclusion (which seems to be justified by Marshall's interpretation of the Bracon flavator (Fabricius) Nees as a basis) it would appear that Cyanopterus Haliday is the same as Campyloneurus Szepligeti, at least in part.

\section{CAMPYLONEURUS Szepligeti.}

Campyloneurus Szepligeti, Term. Fuz., vol. 23, 1900, p. 51.

Type.-Campyloneurus bicolor Szepligeti by present designation.

Cresson's species Bracon faustus and Bracon mavoritus are very likely congeneric with Campyloneurus bicolor Szepligeti as far as can be gleaned from description of the latter. This being the case the name Campyloneurus Szepligeti may be provisionally retained for the species of Campyloneurus that have at least the second segment of the abdomen coarsely sculptured. The Bracon mavoritus Cresson is synonymous with (Bracon) Campyloneurus rugator (Say) and Bracon novitus Cresson is its male. 


\section{CAMPYLONEURUS BICOLORINUS, new name.}

This name is proposed to replace $C$. bicolor Szepligeti, Term. Fuz., vol. 23, 1900, p. 51, not of Brulle, Hist. Nat. Ins. Hym., vol 4, 1846, p. 412, which has been removed from Bracon to Campyloneurus by Cameron, Rec. Albany Mus. Grahamstown, Africa, vol. 1, 1904, p. 155.

\section{ORGILUS ASHMEADI, new species.}

Female.-Length $3.5 \mathrm{~mm}$; tegument mostly smooth, finely granular, subopaque, with inconspicuous whitish pubescence, and stramineous; malar line hardly greater than the greatest diameter of the scape; face mostly shining, with indistinct punctures which are on an average three to four puncture widths apart; second joint of $\mathrm{m} . \mathrm{p}$. six to eight times as long as thick; flagel more than 29 -jointed, somewhat testaceous beneath, brownish above, the first joint at least five times as long as thick; inner side of scape nearly twice as long as the outer side; scape and pedicel brownish above; mesonotum mostly blackish, notauli uniting to form an arcuate impression near the hind third of the dorsulum; furrow between the scutel and dorsulum polished and traversed longitudinally by four nearly equidistant raised lines; scutel brownish; propodeum brownish behind, with only the median longitudinal and basal transverse carinæ present, the former incomplete, extending, but for an interruption near the middle, from the basal transverse carina to the posterior edge of the propodeum; radius attaining a point as near or nearer to the tip of the wing as the transverse cubitus is distant from the stigma on the radius; cubitus not prolonged beyond the transverse cubitus; first discoidal cell forming a trapezium; first abscissa of cubitus a little shorter than the recurrent vein, the latter a little shorter than the first abscissa of the basal vein which latter in turn is a little shorter than the basal vein; second discoidal cell trapezoidal with its longest sides parallel and at least three times as long as the nervulus; middle and hind femora more or less brownish at tip; hind tibiæ blackish; all tarsi brownish to blackish; first segment nearly twice as long as broad at apex, the outer edge of the first plate virtually straight throughout, first segment nearly or quite as long as the two following segments combined; tergum granular, medially more or less tending toward striation; all but the less conspicuous tergal segments at tip of abdomen, dark brown to blackish with a yellowish margin all around the segment; the inconspicuous segments stramineous and with the first tergal segment not margined with yellowish laterally beyond the base; sheaths of the ovipositor approximately as long as the tergum.

Male.-Length $3.5 \mathrm{~mm}$. Sufficiently similar to the female to be readily associated therewith.

Type.-Cat. No. 13800 , U.S.N.M.

Type-locality.-Manila, Philippine Islands.

Thirteen specimens collected by Father Brown.

Named for Dr. W. H. Ashmead. 
ZELE ROSENBERGI, new species.

Female.-Length $11 \mathrm{~mm}$; compared with Zele testaceator Curtis this species may be described as follows: clypeus with the apical margin rather reflexed; scape and pedicel combined apparently not as long as the first joint of the flagel but obviously longer than the second joint of the flagel; vertex with a blackish band extending from eye to eye; thorax rather reddish; radius in hind wings practically straight and gradually diverging from the anterior margin of the wing; second discoidal cell completely closed; wings tinged with fuscous, veins dark brownish; stigma stramineous, infuscated; fore- and mid-coxæ rather stramineous; femora rather reddish; at least mid- and hind-tibiæ reddish, infuscated, their tarsi and spurs rather blackish; apical third of propodeum separated from basal two-thirds by an irregular transverse carina; upper half of abdomen rather infuscated; sheaths of the ovipositor approximately as long as the fourth dorsal segment.

Type.-Cat. No. 13797, U.S.N.M.

Type-locality.-Chanchamayo, East Peru.

Collection Rosenberg.

\section{FAMILY ICHNEUMONIDAE.}

ANILASTUS TRICOLORIPES, new species.

Male.-Length $4.5 \mathrm{~mm}$; briefly characterized by the mostly black or blackish coxæ, the rest of the fore- and mid-legs being mostly yellowish to testaceous, the rest of the hind legs mostly black, the basal sixth of the hind tibiæ yellowish white, the spurs of the same whitish; costulæ not fully developed or merely indicated; basal area parallel sided, narrowly oblong, so that the bounding carinæ are almost in apposition; carina from the basal area to the insertion of hind coxæ distinct throughout.

Type.-Cat. No. 13799, U.S.N.M.

Type-locality.-Europe, Gipsy Moth Laboratory Nos. 1079 and 1065, U. S. Department of Agriculture, Bureau of Entomology.

In a paratype there is a more or less developed lateral longitudinal carina and an arcuate carina between the areola and petiolarea, also the basal area is triangular, indicating considerable range in the variation of the carinæ of the propodeum.

HYPOSOTER DISPARIS, new species.

Female.-Length $6 \mathrm{~mm}$; black; covered with an appressed silvery pubescence that is nowhere so dense as to obscure the tegument except when viewed in certain lights; cheeks in the middle nearly two-thirds as wide as the eye as seen from the side; malar line about two-thirds as long as the mandibles are wide at base; clypeus depressed along the anterior margin, which latter is nearly straight, lateral suture represented by a smooth line that is not appreciably 
longer than one-third the malar line; scape and pedicel yellow in front, brown behind excepting the apical edge which is testaceous; mandibles yellow except apically, where they are castaneous; palpi yellowish; inner edge of eyes slightly shallowly impressed above the middle; greatest diameter of lateral ocellus not as long as the ocellocular line, being only about two-thirds as long; lateral ocellar line as long as the greatest diameter of the lateral ocellus, the postocellar line nearly twice as long as the lateral ocellar line, costula developed, extending to the lateral longitudinal carinæ, second abscissa of radius straight as compared with the first abscissa and about twice as long as the same, stigma at least three times as long as wide or high, areolet oval, punctiform, almost obliterated, the petiole of the same several times longer than the areolet; outer edge of recurrent vein, where it joins the cubitus, on a line with the outer edge of the areolet, the recurrent vein oblique below and extending downward and outward; nervellus extending upward and slightly inward from the submedian vein, which latter is slightly prolonged beyond the former, the nervellus not broken but straight or nearly so; claws pectinate basally; tubercles, tegulæ, distal trochanters, mid- and hind-tibiæ mostly yellow; fore- and mid-coxæ pale, almost castaneous; proximal trochanters, femora, and tarsi of fore- and mid-legs, yellowish to testaceous; the tarsal joints of the mid-legs inclining to dark brown toward the end joint, which latter is blackish; fore tibiæ yellowish in front, darker behind; hind coxæ and femora reddish, infuscated apically; hind tibiæ brownish at base and with the apical third mostly infuscated; hind tarsi similarly colored to the mid-tarsi, but more darkly brownish; tibiæ of mid- and hind-legs sparsely spinose; spurs yellowish; areopetiolarea transversely wrinkled; narrowest part of petiole furrowed laterally; petiole behind the spiracles or postpetiole a little narrower anteriorly than posteriorly, nearly quadrate, half as long as the rest of the petiole and nearly four times as wide at apex as the narrowest part of the petiole; second dorsal segment about as long as wide at apex and about half as wide at base as at apex, its thyridia irregularly rounded and twice as far or a little farther than twice as far from the base as from the lateral edge and about one-sixth as wide as the second dorsal segment is wide at base, spiracle in or a little beyond the middle and about twice as far from the lateral edge as are the thyridia; third dorsal segment nearly parallel-sided, rather compressed apically and about three-fourths or four-fifths as long as the preceding segment; postpetiole finely reticulated, rest of dorsal segment finely sculptured; thyridia and greater part of apical two-fifths of second dorsal segment testaceous; ovipositor when in the resting position hardly exserted, straight and sharp, translucent brownish; sheaths clavate and toward the apex directed slightly upward; plica mostly yellow. 
Male.-Differs little from the female; it is noteworthy, however, that in the male the transverse wrinkles are virtually wanting in the areopetiolarea of the type, that the spiracle of the second dorsal segment is a little before the middle and almost adjoining the lateral edge, and that the pale border of the second dorsal segment is invaded medially by black pigment.

Type.-Cat. No. 13074, U.S.N.M.

Type-locality.-Europe, Gipsy Moth Laboratory, No. 529, Aug. 20 and Nov. 2, 1908; U. S. Department of Agriculture, Bureau of Entomology.

This species bears a close resemblance to Phobocampe crassiuscula (Gravenhorst).

PIMPLA (PIMPLA) PORTHETRIA, new species.

Male.-Length $7 \mathrm{~mm}$.; compared with $P$. instigator, this species differs chiefly as follows: Antennæ entirely black; face dullish, more pubescent; fore and mid legs beyond the trochanters rather yellowish, excepting the mid femora which are infuscated basally and the claws and pulvilli which are blackish; hind legs black throughout except the extreme base of their femora which is yellow, the spurs which are brownish and the claws which are castaneous apically; metapleuræ not striate throughout; dorsal segments apically more or less edged with yellow or yellowish.

Type.-Cat. No. 13077, U.S.N.M.

Type-locality.- Japan, ex Porthetria dispar, Gipsy Moth Laboratory No. 1825, U. S. Department of Agriculture, Bureau of Entomology.

PIMPLA (PIMPLA) DISPARIS, new species.

Female.-Length $15 \mathrm{~mm}$; in size, structure, and sculpture, as well as in color, very like P. examinator Fabricius, from which it differs chiefly as follows:- sides of propodeum separated from the rest by a rather distinct angulation, the propodeum not rounded off domelike; fore legs, with their proximal trochanters yellow beneath, their femora yellowish above, apically; mid-tibiæ mostly reddish, infuscated basally, without a pale band; hind legs with more or less of the apical third of their femora black, their tibiæ and tarsi entirely black or blackish.

Male.-Antennæ entirely black or blackish in the basal third as in the female, the apical two-thirds becoming brown, legs colored as in the female.

Type.-Cat. No. 13078, U.S.N.M.

Type-locality.- Japan, ex Porthetria dispar, Gipsy Moth Laboratory Nos. 1650, 1825, 1647, U. S. Department of Agriculture, Bureau of Entomology. 


\section{$2 \mathrm{BHL}$ Biodiversity Heritage Library}

Viereck, Henry Lorenz. 1911. "Descriptions of one new genus and eight new species of Ichneumon flies." Proceedings of the United States National Museum $40,475-480$.

View This Item Online: https://www.biodiversitylibrary.org/item/53820

Permalink: https://www.biodiversitylibrary.org/partpdf/53289

\section{Holding Institution}

Smithsonian Libraries

\section{Sponsored by}

Smithsonian

\section{Copyright \& Reuse}

Copyright Status: Public domain. The BHL considers that this work is no longer under copyright protection.

This document was created from content at the Biodiversity Heritage Library, the world's largest open access digital library for biodiversity literature and archives. Visit BHL at https://www.biodiversitylibrary.org. 